\title{
GROWTH, COLONIAL SIZE AND SPORULATION OF LYOPHILIZED CULTURES OF THE GENUS TRICHOPHYTON ON AGAR MEDIA
}

\author{
A. RYBNIKÁř \\ Bioveta, 68323 Ivanovice na Hané \\ Received November 1, 1984
}

\begin{abstract}
Rybnikář A.: Growth, Colonial Size and Sporulation of Lyophilized Cultures of the Genus Trichophyton on Agar Media. Acta vet., Brno, 55, 1986: 73-80.

Lyophilized cultures of 4 species of the genus Trichophyton Malmsten 1845 were diluted with saline after one year of storage and inoculated onto agar media. Trichophyton equinum grew best on malt media, T. mentagrophytes on Mycological Agar, T. terrestre on Trichophyton Agars 1, 4 and 5, and T. verrucosum on Sabouraud's agar. The rate of colonial size increase of all the four cultures was highest on Sabouraud's agar, malt media and Mycological Agar. The formation of microconidia showed the highest values on malt media with all the cultures except $T$. terrestre which sporulated best on Sabouraud's agar. It is concluded that malt agar media and Sabouraud's agar are suitable culture media for recultivation of lyophilized dermatophyte cultures.
\end{abstract}

Dermatophyte lyophilizate, recultivation, colonial size, formation of microconidia.

Cultures of microscopic fungi deposited in culture collections as well as those used for production purposes undergo gradual loss of viability on long-term storage. In recultivating frozenlyophilized or otherwise preserved fungal strains it is therefore necessary to choose optimum procedures and conditions that would allow one to obtain viable, well-growing and sporulating cultures. One of the major factors involved is the choice of a suitable culture medium. Its choice may also considerably affect the results of testing fungal cultures for their growth and sporulation capacity and may lead to changes in the characteristics of the strains on passage. These aspects are particularly important in dermatophytic fungi, causative agents of mycoses in numerous animal species and man.

The present study is concerned with the choice of agar culture media for recultivation, growth and sporulation of four species of the genus Trichophyton maintained in the lyophilized state for one year. These were three zoophilic dermatophytes, namely $T$. equinum, T. mentagrophytes and $T$. verrucosum, and one geophilic species, $T$. terrestre, which lives as a saprophyte on keratin structures in soil and very rarely attacks man and animals.

\section{Materials and Methods}

Lyophilized samples of 4 dermatophytic strains, namely Trichophyton equinum (Matruchot et Dassonville 1898) Gedoelst 1902, T. mentagrophytes (Robin) Blanchard 1896, T. terrestre Durie et Frey 1957 and T. verrucosum Bodin 1902, were included in the experiments. After being stored at a refrigerator temperature of +2 to $+8^{\circ} \mathrm{C}$ for one year, they were diluted with saline. The resultant fungal suspensions (logarithmic dilutions of $10^{-5}$ and $10^{-6}$ ) were inoculated in the routine manner onto the following 12 fresh-prepared culture media: Bacto Trichophyton Agar 1 to 7 (Difco), Bacto Mycological Agar (Difco), Bacto Mycobiotic Agar (Difco), Sabouraud's agar (Imuna, Sar. Michalany), agar with malt extract (Imuna) and peptone-enriched (5 g/l) malt agar prepared from fresh brewer's malt. The $\mathrm{pH}$ of all media was adjusted to 6.2 to 6.6.

Incubation was carried out at $+28^{\circ} \mathrm{C}$ under thermostat-controlled conditions. From the 5th day of cultivation, diameters of the colonies were measured (with an accuracy of $0.5 \mathrm{~mm}$ ) in all 


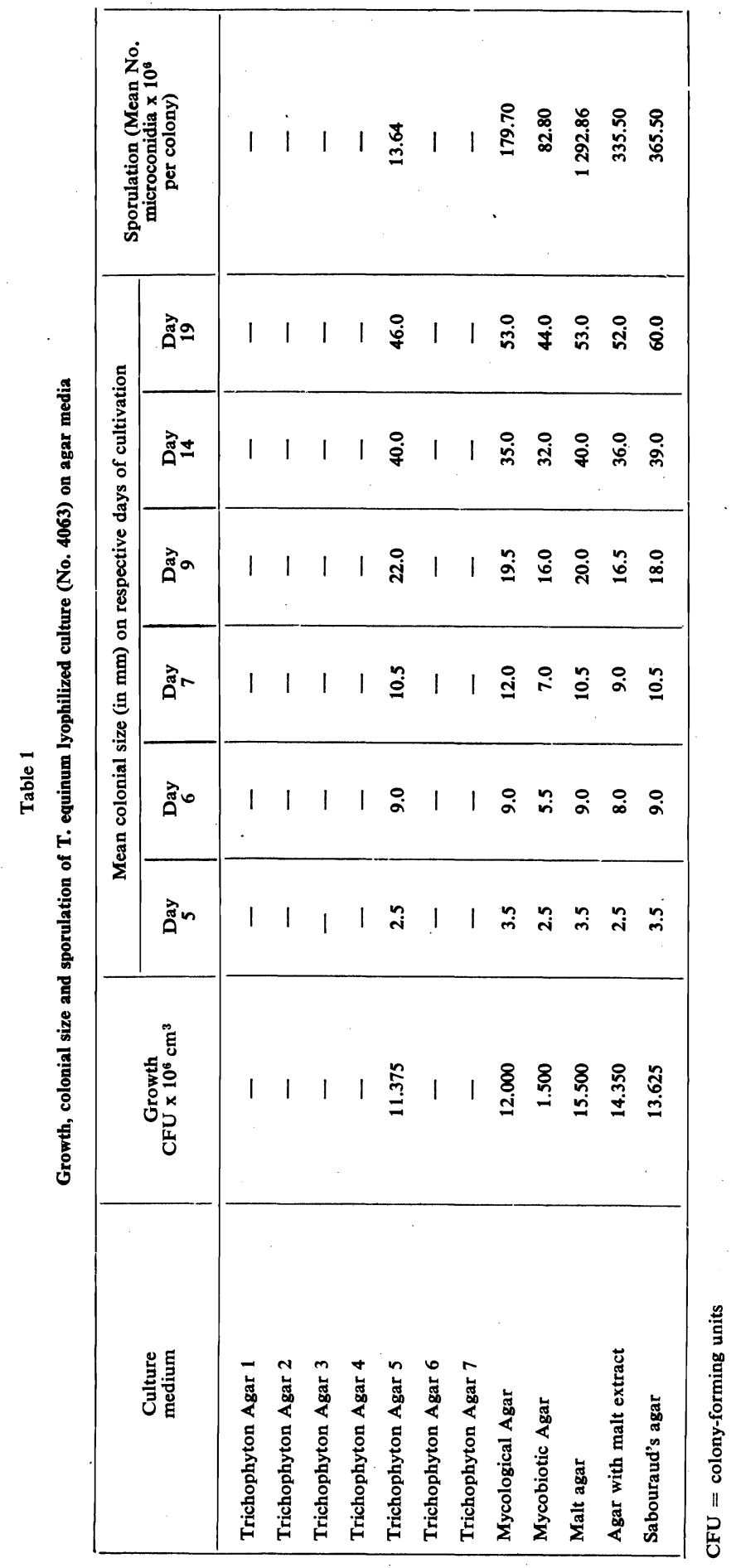


the four strains. After 7 to 9 days of incubation the colonies grown on the individual agar media were counted and the growth was evaluated in terms of colony-forming units (CFU) per $\mathrm{cm}^{3}$ of diluted lyophilizate. After 14 and 19 days of cultivation of $T$. equinum, T. mentagrophytes and $T$. terrestre and of $T$. verrucosum, respectively, five average colonies were withdrawn quantitatively from each experimental variant and shaken in $50 \mathrm{~cm}^{3}$ saline. In the resultant suspensions, numbers of microconidia were determined microscopically using Bürker's counting chamber. The values thus obtained were expressed in terms of mean microconidial number per colony.

\section{Results}

At the dilutions used in our study, $T$. equinum culture from lyophilized samples failed to grow on Trichophyton Agars 1, 2, 3, 4, 6 and 7. The most suitable media for this culture were the two malt media and Sabouraud's agar which were also found to yield the highest values for microconidial number per colony. Colonial size values for this culture increased most rapidly on Sabouraud's agar, the two malt media and Mycological Agar (Table 1).

The growth of T. mentagrophytes culture, evaluated in terms of CFU per $\mathrm{ccm}$ diluted lyophilizate, was best on Mycological Agar and Trichophyton Agar 5. Its highest sporulation was obtained on the two malt media and Mycobiotic Agar. Colonial size of this culture increased most rapidly on Sabouraud's agar, Mycological Agar and on the malt media. No growth of this culture was observed on Trichophyton Agars 4, 6 and 7 (Table 2).

The growth of T. terrestre culture was best on Trichophyton Agars 1, 4 and 5 . The highest values for colonial size and sporulation of this culture were obtained on Sabouraud's agar and Mycological Agar. Satisfactory increases in colonial size were recorded for this strain also on Trichophyton Agar 5 and on the two malt media. Poor colonial size and sporulation were found on Trichophyton Agar 6 and no growth of this culture at all was observed on Trichophyton Agar 7 (Table 3).

With $T$. verrucosum cultures the highest sporulation values were obtained on the malt media. This dermatophytic fungus grew best on Sabouraud's agar, followed by Mycobiotic Agar, Mycological Agar, the malt media and Trichophyton Agar 1. The highest values for colonial size increase were obtained on the malt media and Mycological Agar. No growth of this culture at all was observed on Trichophyton Agars 6 and 7 (Table 4).

\section{Discussion}

The question of suitable isolation media for dermatophytes was previously the subject of a study by Otčenášek et al. (1978). Unlike the present report where lyophilizates of dermatophytic cultures were tested, the study of the aforementioned investigators was made on samples collected from mycotic skin lesions. They found Mycotic Agar (Difco) to be the most suitable substrate for isolation of dermatophytes. They also reported that Sabouraud's dextrose agar proved a good culture medium even when compared with special isolation media. This observation was confirmed by the results of our experiments where inoculation of lyophilized cultures of dermatophytes onto a number of media resulted in approximately equal growth (in terms of CFU per $\mathrm{cm}^{3}$ diluted lyophilizate) on Sabouraud's agar and Mycobiotic Agar in all the strains under study except $T$. equinum. Similar growth was also obtained upon inoculation onto Mycological Agar, the composition of which corresponds to that of Mycobiotic Agar except that it contains no antibiotics. The rate of increase of dermatophyte colony size was highest, for the most part, on Sabouraud's agar 


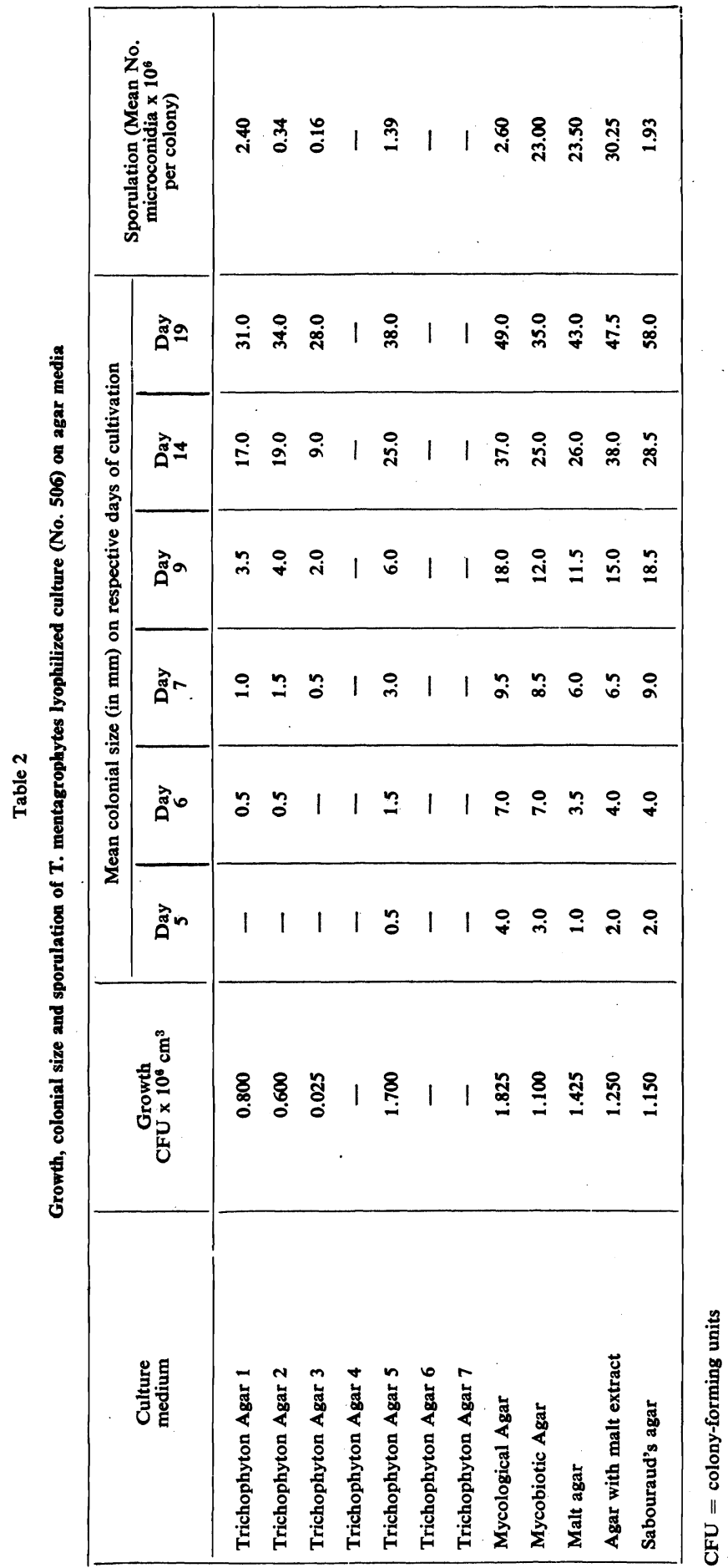




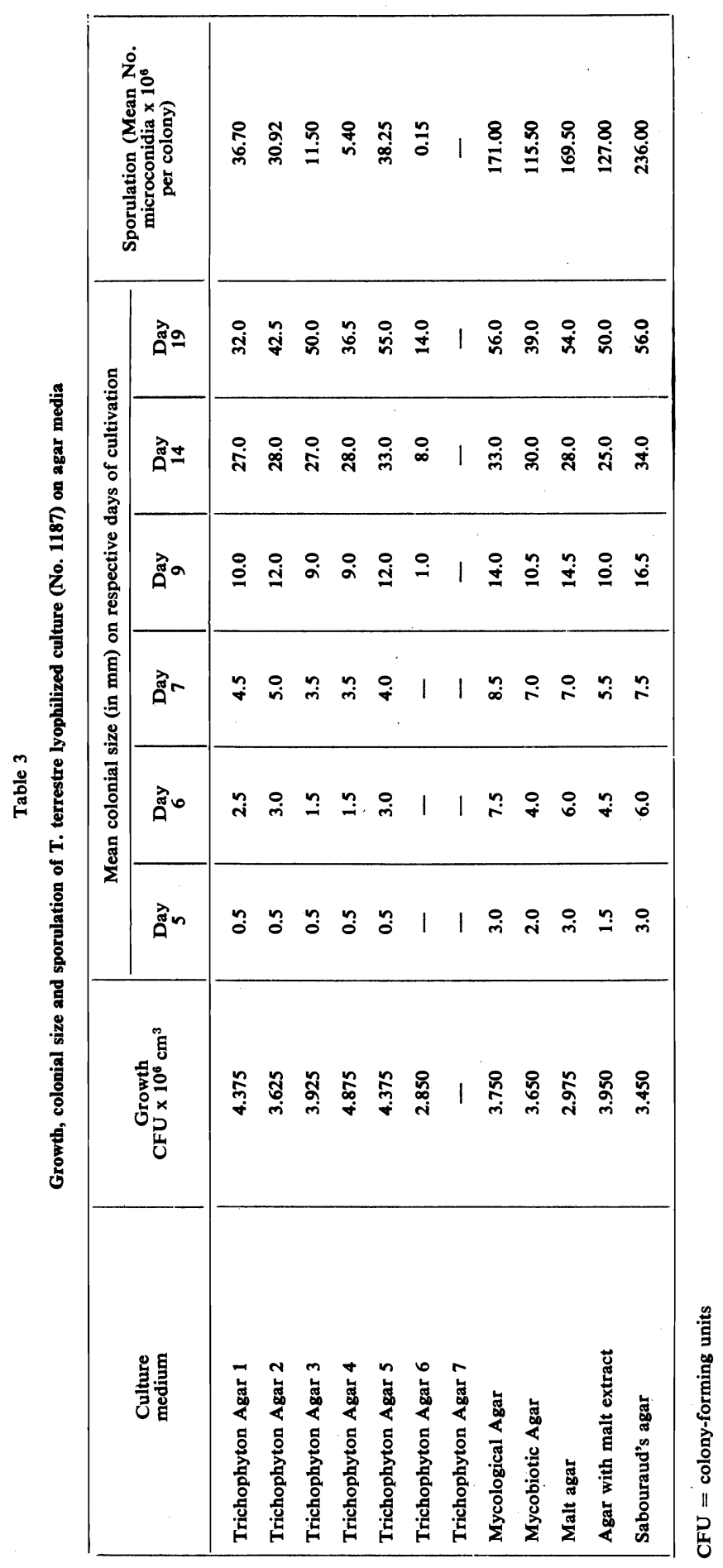




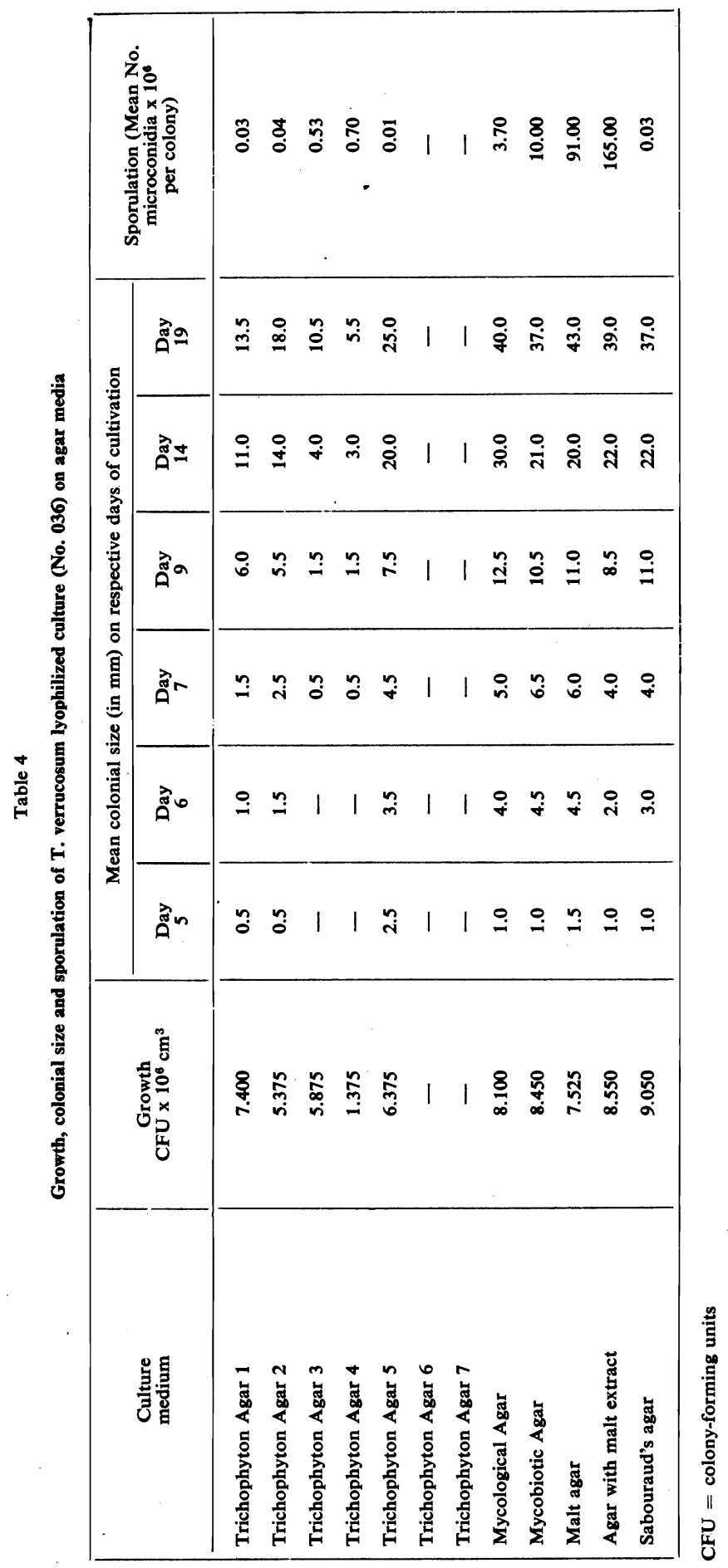


and Mycological Agar, whereas the colonial size values on Mycobiotic Agar were somewhat lower, obviously due to the inhibitory action of antibiotics.

Trichophyton Agars (Difco) proved in most cases unsuitable for recultivation, growth and sporulation of lyophilized dermatophyte cultures. $T$. equinum grew only on Trichophyton Agar 5. Practically no growth of any of the strains under study was observed on Trichophyton Agars 6 and 7 and T. mentagrophytes failed to grow in addition on Trichophyton Agar 4. These results are in keeping with the instructions as to how these media should be used. Being specific, they are designed primarily for differentiation of dermatophyte cultures. The aforementioned substrates can be recommended only for recultivation of $T$. terrestre culture which showed good growth and colonial size on Trichophyton Agars 1 to 5 .

Sporulation of the cultures inoculated onto the agar media was judged by the formation of microconidia whose capacity to survive lyophilization procedures is higher than that of all the other vegetative parts of dermatophytes (Rybnikár et al. 1983). The formation of microconidia in the present study reached the highest values on the two malt media with all the cultures except $T$. terrestre. Moreover, very good values were recorded for growth and colonial size upon inoculation onto these two media with all the cultures under study. Malt agar was previously used with success for dermatophyte cultivation by numerous Soviet investigators. Thus Iva nova (1976) studying morphological characteristics of $T$. verrucosum strains grown on malt agar pointed out good colonial size and formation of micro- and macroconidia of the cultures. Similar results were obtained on malt agar with T. equinum culture by Petrovitch (1975). Poljakov (1981) also found the highest sporulation values for T. equinum and T. verrucosum on malt agar. Salach El Din and Sarkisov (1980) reported that the virulence of a $T$. mentagrophytes strain varied with the culture medium employed and was particularly high upon inoculation onto malt agar. Since the last-mentioned writers did not specify the composition and size of the inoculation doses, their results may be accounted for by the presence of more conidia in the inoculum from malt agar than in those grown on the other media tested in their study.

The results reported in the present study as well as the previous published evidence imply that solid malt culture media can be recommended for isolation of the aforementioned cultures of the genus Trichophyton. The growth of dermatophytes on. these substrates is fully comparable to, and the sporulation of the cultures is in most cases markedly higher than, the results obtained on special foreign media. Sabouraud's agar is a suitable medium with regard to growth and colonial size increase. The rate of colonial size increase and sporulation of cultures of the genus Trichophyton may be increased, e.g., by addition of thiamin, nicotinic acid, mesoinositol and glutamic acid (Ragot and Clerivet 1972), the formation of macroconidia by addition of a $3 \%$ to $5 \%$ sodium chloride solution (Kane and Fischer 1975; Galgóczy 1978) and the formation of chlamydospores may be increased by addition to culture media of L-cystein (Thuy et al. 1981), with the nutritional requirements of individual strains being possibly quite specific.

\section{Kultivační záchytnost, růst a sporulace lyofilizovaných kultur rodu Trichophyton na agarových médiích}

Lyofilizované kultury 4 druhů rodu Trichophyton Malmsten 1845 byly po 1 roce uchovávání ředěny fyziologickým roztokem a vysety na agarové živné půdy. Relativně nejvyšší kultivační záchytnost kultury Trichophton equinun byla zjištěna na sladinkových půdách, $T$. mentagrophytes na Mycological agaru, $T$. terrestre 
na Trichophyton agarech 1,4 a 5 a $T$. verrucosum na Sabouraudově agaru. Rychlost růstu všech kultur byla nejvyšší na Sabouraudově agaru, sladinkových půdách a Mycological agaru, tvorba mikrokonidií na sladinkových médiích s výjimkou $T$. terrestre, který nejlépe sporuloval na Sabouraudově agaru. Sladinkové agarové půdy a Sabouraudův agar představují vhodná živná média pro zpětnou kultivaci lyofilizovaných kultur dermatofytů.

\section{Культивационная задерживаемость, рост и споруляция лиофилизированньх культур $\mathbf{R}$. Trichophyton на агаровой среде}

Лиофилизированные культуры 4 видов рода Trichophyton Malmsten 1845 после годичного хранения разбавлялись физиологическим раствором и высеивались в агаровую питательную среду. Относительно самая большая культивационная задерживаемость культуры Trichophyton equinum была установлена на сусловых почвах, T. mentagrophytes на Mycological agar, T. terrestre - на Trichophyton agar 1, 4, 5 и Т. verrucosum - на агаре Сабурода, сусловых средах п Mycological agar, образование микроконидий - на сусловых средах за исключением $T$. terrestre, спорулирующем лучше всего на агаре Сабурода. Сусловая среда и агар Сабурода представляют собюю подходящую питательную ореду для обратной культивации лиофилизированных культур дерматофитов.

\section{References}

GALGÓCZY, J.: Conidium ontogeny of dermatophytes. Acta microbiol. Acad. Sci. hung., 25, 1978: 55-60.

IVANOVA, L. G.: Kuĺturaĺno-morfologičeskie osobennosti štammov Trichophyton verrucosum raznogo geografičeskogo proischoždenija. Bjul. Vses. ord. Lenina inst. eksp. vet., 25, 1976: $43-48$.

KANE, J. - FISCHER, J. B.: The effect of sodium chloride on. the growth and morphology of dermatophytes and some other keratolytic fungi. Can. J. Microbiol., 21, 1975: 742-749.

OTČENÁŚEK, M. - ŠICH, J. - JANEČKOVÂ, V.: Ke kultivační záchytnosti dermatofytů na izolačních médiích. Suppl. Sb. věd. prací Lék. fak. UK v Hr. Králové, 21, 1978: 133-140.

PETROVIČ, S. V.: Vozbuditěli dermatomikozov lošaděj. Veterinarija (Moskva), 1975, (10): 49-51.

POLJAKOV, I. D.: Aktivnost allergenov iz dermatofitov. Veterinarija (Moskva), 1981, (9): $37-39$.

RAGOT, J. - CLERIVET, A.: Etude des exigences nutritives de quatre souches de Trichophyton verrucosum. Sabour., 10, 1972: 284-297.

RYBNIKÁŘ, A. - DITRICH, O. - PYTELA, F.: Lyofilizace některých kultur dermatofytů. Ces. Mykol., 37, 1983: 93-98.

SALACH EL DIN, A. K. - SARKISOV, A. CH.: Vlijanie pitateĺnoj sredy na patogennost dermatofitov. Bjul. Vses. ord. Lenina inst. eksp. vet., 38, 1980: 76-78.

THUY, N. N. - GALGÓCZY, J. - NOVÁK, E. K.: Morphogenetic effect of L-cysteine on dermatophytes. Acta microbiol. Acad. Sci. hung., 28, 1981: 347-357. 